\title{
Live cell imaging of macrophage/ bacterium interaction demonstrates cell lysis induced by Corynebacterium diphtheriae and Corynebacterium ulcerans
}

\author{
Dulanthi Weerasekera ${ }^{1 \dagger}$, Jonas Hahn ${ }^{2 \dagger}$, Martin Herrmann ${ }^{2}$ and Andreas Burkovski ${ }^{*}$ (1)
}

\begin{abstract}
Objectives: In frame of a study to characterize the interaction of human macrophage-like cells with pathogenic corynebacteria, Corynebacterium diphtheriae and Corynebacterium ulcerans, live cell imaging experiments were carried out and time lapse fluorescence microscopy videos were generated, which are presented here.

Data description: The time lapse fluorescence microscopy data revealed new insights in the interaction of corynebacteria with human macrophage-like THP-1 cells. In contrast to uninfected cells and infections with non-pathogenic C. glutamicum used as a control, pathogenic C. diphtheriae and C. ulcerans showed highly detrimental effects towards human cells and induction of cell death of macrophages.
\end{abstract}

Keywords: Cytotoxicity, Diphtheria, Live cell imaging, Phagocytes, THP-1, Time lapse fluorescence microscopy

\section{Objective}

Within the actinobacteria (high G+C DNA content Gram-positives) the genus Corynebacterium forms together with the genera Mycobacterium, Nocardia and Rhodococcus the CMNR group, which is characterized by a complex, mycolic acid-containing cell wall structure [1]. At the time of writing, 132 species and 11 subspecies were assigned to the genus [2], with more than half of these isolated from animal and human sources or clinical material [3]. The most prominent member of the genus is Corynebacterium diphtheriae, which forms together with Corynebacterium ulcerans and Corynebacterium pseudotuberculosis the group of toxigenic corynebacteria [4], based on their common characteristic that they can produce diphtheria toxin (DT), a potent exotoxin, after being lysogenized by tox gene-carrying corynephages [5]. DT is

\footnotetext{
*Correspondence: andreas.burkovski@fau.de

${ }^{\dagger}$ Dulanthi Weerasekera and Jonas Hahn contributed equally to the manuscript (shared first authorship)

${ }^{1}$ Friedrich-Alexander-Universität Erlangen-Nürnberg, Staudtstr. 5, 91058 Erlangen, Germany

Full list of author information is available at the end of the article
}

responsible for the high fatality rate of diphtheria with an overall death toll of 5 to $10 \%$ and a fatality rate up to $20 \%$ among children younger than five and in unvaccinated or not sufficiently protected individuals [6]. Interestingly, $C$. diphtheriae and C. ulcerans strains are not only able to adhere to and invade epithelial cells, but may also persist inside macrophages after being taken up by these phagocytes [7]. Recent publications showed that $C$. diphtheriae as well as $C$. ulcerans may interfere with phagolysosome maturation in murine and human macrophages after phagocytosis [8-11]. Most recently, a study combining of fluorescence microscopy, cytotoxicity assays and fluorescence-activated cell sorting revealed that these pathogenic corynebacteria induce necroptosis in human phagocytic cell lines [12]. It was suggested that survival in macrophages and subsequent necrotic lysis of cells may be mechanisms for dissemination of $C$. diphtheriae and C. ulcerans within the host and support colonization of host tissues far distant from the infection site. Within this context, a collection of time lapse fluorescence microscopy videos was taken, which are presented here. 
Table 1 Overview of data files/data sets

\begin{tabular}{llll}
\hline Label & Name of data file/data set & File types (file extension) & $\begin{array}{c}\text { Data repository and identifier (DOI } \\
\text { or accession number) }\end{array}$ \\
\hline Data set 1 [14] & uninfected cells.mp4 & Media file (mp4) & https://doi.org/10.6084/m9.figshare.9878708 \\
Data set 2 [15] & C. glutamicum-macrophage interaction.mp4 & Media file (mp4) & https://doi.org/10.6084/m9.figshare.9878687 \\
Data set 3 [16] & C. ulcerans-macrophage interaction.mp4 & Media file (mp4) & https://doi.org/10.6084/m9.figshare.9878681 \\
Data set 4 [17] & C. diphtheriae-macrophage interaction.mp4 & Media file (mp4) & https://doi.org/10.6084/m9.figshare.9810536 \\
\hline
\end{tabular}

\section{Data description Live cell imaging}

THP-1 human monocytic cells [13] were cultured at $37^{\circ} \mathrm{C}$ in 10\% fetal calf serum (FCS; Life Technologies, Carlsbad, CA, USA) supplemented Roswell Park Memorial Institute (RPMI) medium 1640 (Thermo Fisher Scientific, Waltham, MA, USA) containing $100 \mathrm{U} \mathrm{ml}^{-1}$ penicillin and streptomycin, respectively. For live cell imaging assays, cells were seeded in a density of $1.2 \times 10^{5}$ cells on 8 wells sterile glass bottom $\mu$-slides (Thermo Fisher Scientific, Waltham, MA, USA) and differentiated by addition of $10 \mathrm{ng} \mathrm{ml}^{-1}$ phorbol 12-myristate 13-acetate (PMA; Sigma, Darmstadt, Germany) $24 \mathrm{~h}$ prior to infection. The cells were washed two times with phosphatebuffered saline (PBS; B.Braun, Melsungen, Germany) to remove non-adherent cells and fresh medium was added. Cells were incubated at $37^{\circ} \mathrm{C}$ under humified atmosphere and $5 \% \mathrm{CO}_{2}$ at least 20 min prior to infection with bacteria. Staining was carried out using $0.1 \mu \mathrm{g} \mathrm{ml}^{-1}$ Hoechst 33342 (Thermo Fisher Scientific, Waltham, MA, USA) and $1 \mu \mathrm{g} \mathrm{ml}^{-1}$ propidium iodide (Invitrogen, Carlsbad, CA, USA) in PBS. For infection, overnight cultures of green fluorescent protein (GFP)-expressing corynebacteria [12] grown in kanamycin-containing Heart infusion (HI) medium (Becton-Dickinson, Sparks, MD, USA) were inoculated to an $\mathrm{OD}_{600}$ of 0.1 in fresh medium, harvested at the beginning of the exponential growth phase $\left(\mathrm{OD}_{600}\right.$ approx. 0.4 to 0.6$)$ and used to infect macrophages at an MOI of 25. Micrographs were taken using a BZ-X710 microscope (Keyence, Neu-Isenburg, Germany) and the corresponding the BZ-X710 software package (Keyence, Neu-Isenburg, Germany).

\section{Time lapse fluorescence microscopy}

From the micrographs taken every 15 min over a time period of $20 \mathrm{~h}$, time lapse videos were produced using the BZ-X710 software (Keyence, Neu-Isenburg, Germany) (Table 1). Bacteria are stained in green due to GFP expression, nuclei appear in blue due to DNA staining by Hoechst 33342 (Thermo Fisher Scientific, Waltham, MA, USA) and dead cells with defect membrane barrier are stained red by propidium iodide (Invitrogen, Carlsbad CA, USA).

Data sets 1 to 4 (Table 1) show the behavior of uninfected cells and cells infected with nonpathogenic $C$. glutamicum ATCC13032 as well as pathogenic C. diphtheriae $\mathrm{HC} 04$ and C. ulcerans 809, respectively. The uninfected cells revealed only a small amount of propidium iodide-stained dead cells over the incubation period of $20 \mathrm{~h}(15 \pm 4 \%$ dead cell). Infection with nonpathogenic C. glutamicum ATCC13032 showed a slightly increased number of dead cells ( $25 \pm 5 \%$ dead macrophages), while propagation of bacteria was poor. In contrast, infection with $C$. diphtheriae resulted in strong induction of cell death $(75 \pm 5.6 \%$ dead cells). Strong bacterial growth and formation of micro-colonies in the medium was detectable in this case. Also in case of C. ulcerans strong detrimental effects were observed with $85 \pm 12 \%$ dead phagocytes after $20 \mathrm{~h}$ of infection. Compared to C. diphtheriae, enhanced phagocytosis of bacteria and bacterial growth within phagocytes was observed [14-17].

\section{Limitations}

The data sets presented here support and extend results on the interaction of Corynebacterium species; i.e. C. diphtheriae, C. glutamicum and C. ulcerans, with different phagocytic cells published previously [8-12]. Limitations of the data sets are (i) the use of only one strain per species applied, (ii) the analysis of only one human macrophage-like cell line and (iii) the use of only one MOI in the infection experiments.

\footnotetext{
Abbreviations

DT: diphtheria toxin; FCS: fetal calf serum; GFP: green fluorescent protein; MOI: multiplicity of infection; $\mathrm{OD}_{600}$ : optical density at $600 \mathrm{~nm}$ wavelength; PBS: phosphate-buffered saline; PMA: phorbol 12-myristate 13-acetate; RPMI: Roswell Park Memorial Institute.
}

\section{Acknowledgements}

DW gratefully acknowledges support by the Deutscher Akademischer Austauschdienst (DAAD) and the Friedrich-Alexander-Universität ErlangenNürnberg in frame of the "Förderung von Frauen in Forschung und Lehre (FFL)"program. 


\section{Authors' contributions}

Infection experiments and life cell imaging experiments were carried out by $\mathrm{DW}$ and $\mathrm{JH} ; \mathrm{MH}$ and $\mathrm{AB}$ were responsible for conceptualization and supervision of experiments; writing of the draft as well as project administration was carried out by AB. All authors read and approved the final manuscript.

\section{Funding}

This research received no external funding

\section{Availability of data materials}

The data described can be freely and openly accessed on https://figshare. com/. Please see Table 1 and reference list [14-17] for details and direct links to the data.

\section{Ethics approval and consent to participate}

Not applicable.

\section{Consent for publication}

Not applicable.

\section{Competing interests}

The authors declare that they have no competing interests.

\section{Author details}

${ }^{1}$ Friedrich-Alexander-Universität Erlangen-Nürnberg, Staudtstr. 5, 91058 Erlangen, Germany. ${ }^{2}$ Friedrich-Alexander-Universität Erlangen-Nürnberg, Universitätsklinikum Erlangen, Erlangen, Germany.

Received: 13 September 2019 Accepted: 15 October 2019 Published online: 25 October 2019

\section{References}

1. Burkovski A. Cell envelope of corynebacteria: structure and influence on pathogenicity. ISRN Microbiol. 2013. https://doi.org/10.1155/2013/93573 6.

2. List of prokaryotic names with standing in nomenclature. http://www. bacterio.net/corynebacterium.html. Accessed 03 Sept 2019.

3. Tauch A, Sandbote J. The family Corynebacteriaceae. In: Rosenberg E, Delong E, Lory S, Stackebrandt E, Thompson F, editors. The prokaryotes. Berlin: Springer; 2014. p. 239-77.

4. Riegel P, Ruimy R, De Briel D, Prévost G, Jehl F, Christen R, Monteil H. Taxonomy of Corynebacterium diphtheriae and related taxa, with recognition of Corynebacterium ulcerans sp. nov. nom. rev. FEMS Microbiol Lett. 1995;126:271-6
5. Sangal V, Hoskisson PA. Corynephages: infections of the infectors. In: Burkovski A, editor. Corynebacterium diphtheriae and related toxigenic species. Dordrecht: Springer; 2014. p. 67-81.

6. Hessling M, Feiertag J, Hoenes K. Pathogens provoking most deaths worldwide: a review. Biosci Biotechnol Res Commun. 2017;10:1-7.

7. Burkovski A. Pathogenesis of Corynebacterium diphtheriae and Corynebacterium ulcerans. In: Singh SK, editor. Human emerging and re-emerging infections, vol. 2. Hoboken: Wiley Blackwell Press; 2016. p. 697-708.

8. Hacker E, Ott L, Schulze-Luehrmann J, Lührmann A, Wiesmann V, Wittenberg T, Burkovski A. The killing of macrophages by Corynebacterium ulcerans. Virulence. 2016;7:45-55.

9. Ott L, Hacker E, Kunert T, Karrington I, Etschel P, Lang R, Wiesmann V, Wittenberg T, Singh A, Varela C, Bhatt A, Sangal V, Burkovski A. Analysis of Corynebacterium diphtheriae macrophage interaction: dispensability of corynomycolic acids for inhibition of phagolysosome maturation and identification of a new gene involved in synthesis of the corynomycolic acid layer. PLoS ONE. 2017;12:e0180105.

10. Weerasekera D, Fastner T, Lang R, Burkovski A, Ott L. Of mice and men: interaction of Corynebacterium diphtheriae strains with murine and human phagocytes. Virulence. 2019;10:414-28.

11. Weerasekera D, Möller J, Kraner ME, Azevedo Antunes C, MattosGuaraldi AL, Burkovski A. Beyond diphtheria toxin: cytotoxic proteins of Corynebacterium ulcerans and Corynebacterium diphtheriae. Microbiology. 2019;165:876-90.

12. Weerasekera D, Hahn J, Herrmann M, Burkovski A. Induction of necrosis in human macrophage cell lines by Corynebacterium diphtheriae and Corynebacterium ulcerans strains isolated from fatal cases of systemic infections. Int J Mol Sci. 2019;20:E4109.

13. Tsuchiya S, Yamabe M, Yamaguchi Y, Kobayashi Y, Konno T, Tada K. Establishment and characterization of a human acute monocytic leukemia cell line (THP-1). Int J Cancer. 1980;26:171-6.

14. Weerasekera D, Hahn J, Herrmann M, Burkovski A. Data set 1. figshare. 2019. https://doi.org/10.6084/m9.figshare.9878708.

15. Weerasekera D, Hahn J, Herrmann M, Burkovski A. Data set 2. figshare. 2019. https://doi.org/10.6084/m9.figshare.9878687.

16. Weerasekera D, Hahn J, Herrmann M, Burkovski A. Data set 3. figshare. 2019. https://doi.org/10.6084/m9.figshare.9878681.

17. Weerasekera D, Hahn J, Herrmann M, Burkovski A. Data set 4. figshare. 2019. https://doi.org/10.6084/m9.figshare.9810536.

\section{Publisher's Note}

Springer Nature remains neutral with regard to jurisdictional claims in published maps and institutional affiliations.
Ready to submit your research? Choose BMC and benefit from:

- fast, convenient online submission

- thorough peer review by experienced researchers in your field

- rapid publication on acceptance

- support for research data, including large and complex data types

- gold Open Access which fosters wider collaboration and increased citations

- maximum visibility for your research: over 100M website views per year

At BMC, research is always in progress.

Learn more biomedcentral.com/submissions 